\title{
Deontological aspects of the nursing profession: understanding the code of ethics
}

\author{
Vivencia deontológica de la enfermería: develando el código de ética profesional \\ Vivência deontológica da enfermagem: desvelando o código de ética profissional
}

\section{Terezinha Nunes da Silva', Maria Eliane Moreira Freire", Monica Ferreira de Vasconcelos', Sergio Vital da Silva Junior"I', Wilton José de Carvalho Silva'"I, Patrícia da Silva Araújo', Allan Victor Assis Eloy' \\ ' Universidade Federal da Paraíba, Health Sciences Center, Lauro Wanderley University Hospital. João Pessoa, Paraíba, Brazil. "Universidade Federal da Paraíba, Center for Health Sciences, Department of Clinical Nursing. João Pessoa, Paraíba, Brazil. \\ I"' Universidade Federal da Paraíba, Undergraduate Program in Nursing. João Pessoa, Paraíba, Brazil.}

How to cite this article:

Silva TN, Freire MEM, Vasconcelos MF, Silva Jr SV, Silva WJC, Araújo PS, et al. Deontological aspects of the nursing profession: understanding the code of ethics. Rev Bras Enferm [Internet]. 2018;71(1):3-10.

DOI: http://dx.doi.org/10.1590/0034-7167-2016-0565

Submission: 12-08-2016 Approval: 03-06-2017

\begin{abstract}
Objective: to investigate nursing professionals' understanding concerning the Code of Ethics; to assess the relevance of the Code of Ethics of the nursing profession and its use in practice; to identify how problem-solving is performed when facing ethical dilemmas in professional practice. Method: exploratory descriptive study, conducted with 34 (thirty-four) nursing professionals from a teaching hospital in João Pessoa, PB - Brazil. Results: four thematic categories emerged: conception of professional ethics in nursing practice; interpretations of ethics in the practice of care; use of the Code of Ethics in the professional practice; strategies for solving ethical issues in the professional practice. Final considerations: some of the nursing professionals comprehend the meaning coherently; others have a limited comprehension, based on jargon. Therefore, a deeper understanding of the text contained in this code is necessary so that it can be applied into practice, aiming to provide a quality care that is, above all, ethical and legal.
\end{abstract}

Descriptors: Ethics; Ethics Professional; Codes of Ethics; Ethical Theory; Nursing.

\section{RESUMO}

Objetivo: verificar o entendimento de profissionais de enfermagem acerca do Código de Ética; averiguar a relevância do Código de Ética para os profissionais de enfermagem e sua utilização na prática; identificar como se dá a resolutividade diante de dilemas éticos na prática profissional. Método: estudo exploratório, descritivo, envolvendo 34 (trinta e quatro) profissionais de enfermagem de um hospital universitário em João Pessoa-PB. Resultados: emergiram quatro categorias temáticas: concepção do saber ético profissional no exercício da enfermagem; inferências éticas do profissional na prática assistencial; utilização do Código de Ética no exercício profissional; estratégias resolutivas dos imbróglios éticos no exercício profissional. Considerações finais: parte dos profissionais de enfermagem apreende, de forma coerente, seu significado; outros, apresentam compreensão fragilizada e permeada de jargões. Nesse sentido, é imprescindível haver maior compreensão das diretrizes contidas nesse código, para que ele seja aplicado na prática assistencial com o intuito de ofertar cuidados de qualidade e, sobretudo, com respaldo ético e legal.

Descritores: Ética; Ética Profissional; Código de Ética; Deontologia; Enfermagem.

\section{RESUMEN}

Objetivo: Comprobar el entendimiento de los profesionales de enfermería acerca del Código de Ética; averiguar la relevancia del Código de Ética de los profesionales de enfermería y su utilización en la práctica; identificar la mecánica de resolución de los dilemas éticos en la práctica profesional. Método: estudio exploratorio, descriptivo, involucrando 34 (treinta y cuatro) profesionales de enfermería de un hospital universitario en João Pessoa, Paraíba. Resultados: han surgido cuatro categorías temáticas: concepción del saber ético profesional en el ejercicio de la enfermería; inferencias éticas del profesional en la práctica 
asistencial; utilización del Código de Ética en el ejercicio profesional; estrategias resolutivas de los embrollos (imbroglios) éticos en el ejercicio profesional. Consideraciones finales: parte de los profesionales de enfermería aprehende, de forma coherente, su significado; otros presentan una comprensión fragilizada y permeada de jergas. Por esta razón, es imprescindible que haya una mejor comprensión de las directivas contenidas en este código, para poder aplicarlo en la práctica asistencial con el intuito de ofrecer cuidados de calidad con respaldo ético y legal.

Descriptores: Ética; Ética Profesional; Código de Ética; Deontología; Enfermería.

\section{CORRESPNDING AUTHOR Monica Ferreira de Vasconcelos E-mail: vaskoncelos.vaskoncelos@hotmail.com}

\section{INTRODUCTION}

Nursing is an interdisciplinary field that contributes to the promotion of health and the prevention of diseases, aiming to deliver assistance with no damage caused by malpractice, negligence or recklessness and to comply and demand compliance with ethical principles and laws that regulate the profession.

It is important to emphasize that Nursing has its own body of scientific and technical knowledge, built and reproduced by a set of social, ethical and political practices carried out through teaching, research and care. Its objectives are accomplished by providing services to the person, the family and the community, within their life context and circumstances ${ }^{(1)}$.

Nursing professionals are historically known for their caring and compassionate attitude towards suffering patients, but they are also acknowledged for their success in the battle for rights and for having their space recognized among other health professionals. However, they are still advancing in some aspects regarding respect in the work environment, attitude towards ethical conflicts and personal positions.

In Brazil, discussions about Nursing ethics arose in 1951 and started increasing in 1955. The first Nursing Code of Ethics, approved in 1958, was developed by religious nurses who aimed to achieve more security in the professional practice, following the regulation of different occupations. As the codes of ethics are part of the legislation that regulates the profession, its principles have force of law and its violations can be punished ${ }^{(2)}$.

In nursing practice, the professionals often face situations in which they must choose between two or more alternatives. For this, reflection, discussion and advisement are necessary, considering the specific knowledge, values, ethical and legal principles and the norms or rules of conduct intrinsic to the profession. The decisions taken in the health area practice imply interventions on other human beings, often in situations of frailty and/or vulnerability ${ }^{(3)}$.

In addition of having technical knowledge, nursing professionals must have an ethical commitment and to be in constant search for updating themselves to avoid iatrogenesis in their professional practice. Therefore, it is imperative that nursing professionals are familiar with the ethical, civil and penal responsibilities of their professional actions and also with their rights and duties, in order to avoid negligence, malpractice or recklessness. The empowerment of nursing as a profession and a science relies on the apprehension and practical use of this knowledge.

Therefore, this study aims to expand the debate about the Nursing Code of Ethics, highlighting its relevance to guide the professional in their practice as a member of the healthcare team, and to stimulate the promotion of actions to meet the ethical demands for the health assistance provided to the Brazilian population. Therefore, this study intends to defend a nursing care that is safe, competent, humanized and aware of its rights and duties.

\section{OBJECTIVE}

To investigate nursing professionals' understanding concerning the Code of Ethics; to assess the relevance of the Code of Ethics for nursing professionals and its use in practice; to identify how problem-solving is performed when facing ethical dilemmas in professional practice.

\section{METHOD}

\section{Ethical aspects}

Throughout the development of this study, the ethical principles established in Resolution 466/2012 of the National Health Council ${ }^{(4)}$ were followed. The research protocol was approved by the Research Ethics Committee of the Lauro Wanderley Teaching Hospital, Federal University of Paraiba.

\section{Study type}

This is an exploratory study, which allows the researcher to define the research problem and to choose the most appropriate techniques for the investigation ${ }^{(5)}$, with qualitative approach, aiming to understand the social dynamics that cannot be quantified within the explanation of the beliefs, aspirations and values and to allow a better understanding of feelings ${ }^{(6)}$.

\section{Methodological procedures}

A structured questionnaire with open and close-ended questions was used to assess data on the characterization of the participants, such as: age, gender, marital status, professional training, function, time of practice and data related to the specific objectives of the study.

\section{Study setting}

The study was conducted with professionals from the nursing team of a teaching hospital in the city of João Pessoa. The hospital, considered a reference institution in the state of Paraíba, offers specialized consultations in the ambulatory service and assistance in several clinics in the hospitalization area.

\section{Data source}

A non-probabilistic sampling technique was used, selecting the participants by availability ${ }^{(7)}$. The sample consisted of 34 
(thirty four) nursing professionals who met the following inclusion criteria: belong to one of the nursing professional categories and be working in the institution during the period of data collection. The professionals who were members of the hospital's Nursing Ethics Board (CEEn) and/or those who developed any activity in the Regional Nursing Council of Paraíba were excluded from the sample. It is appropriate to mention that their consent was obtained through a Consent Form. To ensure their anonymity, they were randomly assigned from R01 to R34.

\section{Data collection and organization}

Data collection took place from April to May 2015, when the participants that were already informed about the study received the form and, within a period of 48 to 72 hours, filled and returned it to the researchers. The data were transcribed, organized into a table and subjected to critical reading.

\section{Data analysis}

The objective data were tabulated using Microsoft Excel ${ }^{\circledR}$ and analyzed descriptively using frequency distribution. The subjective data were analyzed qualitatively, through the technique of content analysis ${ }^{(8)}$, based on the responses collected. First, the transcripts of the statements of the participants were read, then the data and the arguments related to the objective of the study were selected. In order to understand the core meaning of the participants' answers, considering the frequency of data that give meaning to the object analyzed, the analysis followed the steps of pre-analysis, exploration of the material, treatment of results and interpretation.

After the analysis of the data, four categories emerged: Category I - Conception of professional ethics in nursing practice; Category II - Interpretations of ethics in the practice of care; Category III - Use of the Code of Ethics in the professional practice; Category IV - Strategies for resolving ethical issues in the professional practice. The topic categories were discussed based on the relevant literature.

\section{RESULTS}

A total of 34 (thirty-four) nursing professionals participated in the study. Of these, 32 (thirty-two) were female; 15 (fifteen) were nurses, 9 (nine) were nursing technicians and 10 (ten) were nursing assistants. Regarding the age group, 15 (fifteen) participants were between 28 (twenty eight) and 39 (thirty nine) years old; 17 (seventeen) were between 40 (forty) and 59 (fifty-nine) years; and 2 (two) were 60 (sixty) years old or older.

Regarding nursing experience, 22 (twenty-two) of the participants were practicing nursing for at least two decades; 12 (twelve) were practicing for more than 21 (twenty-one) years; and five (5) were practicing for over 30 (thirty) years.

Regarding professional training, 12 (twelve) participants had a level of education higher than the job required. Of these, 3 (three) had technical training and worked as nursing assistants; 4 (four) had completed undergraduate studies - 2 (two) in Nursing and 1 (one) in Social Work - but worked as nursing technician; 2 (two) were attending a Nursing undergraduate course, but worked as nursing assistants; and 3 (three) had graduate degrees - two (2) certified specialists and one with a master's degree.

Regarding training courses about the Nursing Code of Ethics, 6 (six) participants reported they participated in a training course on the subject. Of these, one reported training in the institution he works and the others reported they sought for this knowledge in other care and teaching institutions. Twenty-eight (28) professionals reported they had never received training in this area.

\section{Category I: Conception of professional ethics in Nursing practice}

Most of the professionals participating in the study emphasized the relationship between the Nursing Code of Ethics and the norms, rules, guidelines, legislation, set of data or information, and legal documents or instruments regarding the legal practice of nursing. This category defined the Code of Professional Ethics as follows:

[...] set of rules, values, principles and norms [...]. (R4)

It is a guideline of the rights and duties of the nursing professional [...]. (R5)

It is the law of professional practice [...]. (R12)

A legal instrument that guides the practice of the profession [...]. (R23)

A document addressing the rights and duties, responsibilities and prohibitions related to nursing professionals [...]. (R25)

However, some participants attributed generic or vague concepts or use jargon to describe the Code of Ethics, demonstrating a limited and inconsistent understanding of the subject, as follows:

[...] a persons' behavior when facing particular situations and the way their expressions are presented in their social environment [...]. (R15)

Ethics is centered on relationships with society and on human behavior. (R24)

It is the fulfillment of duties and the respect to the profession and to the clients. (R33)

It is the code that governs the nursing statute. (R34)

It is our professional guide [...]. (R7)

It is the "compass" of the nursing professional in their daily life. (R16)

Category II: Interpretations of ethics in the practice of care This category emerged from expressive positive affirmations about the relevance of the Code of Ethics for the professional actions, since it provides confidence in aspects related to the technical procedure, the basis of care, patient safety, professional responsibility, the distinction between right and 
wrong, interpersonal relationships, legal support and appropriateness and uniformity in actions, as according to some testimonies:

[...] it supports us, guides us, gives us direction on how to act and work. (R2)

[...] the foundation for our work is found on the Code of Ethics [...]. (R7)

[...] it gives me confidence to act as a nurse. (R9)

[...] it is essential for the professional and for the safety of the patient, the family and the community. (R11)

Without it we could not tell right from wrong [...]. (R16)

[...] so that the activities are carried out uniformly. (R28)

Some of the participants related the relevance of the Code of Ethics to the establishment of limits by the professionals, to the extension of the knowledge regarding ethical aspects, to the possibility of avoiding problems in the work sectors and to the diligence with the profession and with the patients' health, as according to the following statements:

[...] it is a profession where values are more than material, they are human, but they need limits. (R2)

[...] because when obeying the code the professionals will know their limits. (R5)

[...] increase the knowledge in the professional practice. (R4)

[...] avoid problems at work, because this law defends us in some situations. (R10)

[...] because they are the main representation of the care for the patient's health [...]. (R15)

[...] it is related to professionals, professional organizations, employers, professional secrecy and guidance in the field of research, scientific production and advertising. (R22)

Under this approach, some participants in the study demonstrated interest in orientations and emphasized their expectation to increase their knowledge about the Code of Ethics of their profession. They also pointed out difficulties to carry out activities based on professional ethics, and suggested possibilities for training and updating information:

[...] about changes and new guidelines regarding the Code of Ethics, which could be in writing or verbal presentations. (R1)

[...] to better understand what is written in the Code. (R2)

[...] possible recycling in all sectors through lectures. (R6)

[...] clarification on the issue of warnings, suspension, and to what extent are we protected by the Code. (R7)
About conducts when perceiving an ethical violation. What steps to take. (R16)

How to defend ourselves and refuse actions that are not our responsibility. (R17)

[...] a review about these topics, especially regarding rights and duties. (R20)

With critical and reflexive debates addressing, above all, the role of nursing in relation to other categories, discussing the issue of preserving the autonomy of nursing. (R27)

\section{Category III: Use of the Code of Ethics in the professional practice}

This category assessed the use of the Code of Ethics by the participants in the practice of their professional activities. The study showed that most of the participating professionals use the Code of Ethics when carrying out their work. However, an obligation relationship was perceived, opposed to an ethical conscience of legal and genuine critical responsibility in the actions, which should be expected from the professional. This is shown on these reports:

[...] it is the guideline for the issues so there can be demands and/or punishment. (R2)

Because I care for my reputation as a professional, and then I'm bound to use it. (R6)

Because if I do not obey it, I can suffer its penalties. (R12)

Because the professionals are evaluated by their actions, so they are qualified by the Code of Ethics. (16)

[...] is the legal support of our practice, guiding all our activities and preventing the professional from being held accountable. (R27)

As far as I know, it's the rules of the profession. (R34)

Some of the participants emphasized the use of the Code of Ethics as a guiding tool and a contribution for the legal and ethical practice of the nursing profession. They expressed that they conceive the Code of Ethics as an inherent part of their professional posture and that they rely on it to succeed in their professional activities. These statements show their perspective:

If there were no Code of Ethics, there would be no discipline and correct guidance to professionals. (R1)

By using it I follow the correct direction regarding my professional posture. (R5)

Because I value a care free of negligence and malpractice, to deliver a dignified, comprehensive and humanitarian assistance with commitment and loyalty. (R14)

To be sure that I am acting correctly in my professional practice. (R20) 
I use it to support my actions in my professional practice. (R26)

On the other hand, some of the interviewees were emphatic in declaring that they did not use the Code of Ethics and pointed out the difficulties to carry out their activities correctly, as they emphasize in their statements:

I don't know it thoroughly, I work and I act mechanically. (R4)

It is not always possible, because I deal with several types of professionals from other areas and with laymen, so sometimes I can't. (R11)

I only act within my possibilities. I do not always use it because there are barriers such as our superiors. (R32)

\section{Category IV: Strategies for resolving ethical issues in the professional practice}

Regarding ethical conflicts in the work context, participants reported that professional ethical conflicts are solved through debates and team meetings, which are considered effective interventions for the resolution of ethical issues in the work sector, as these statements shows:

[...] the problems are discussed and solved in the own sector, intermediated by the superiors. (R1)

Discussing it with the immediate superior; demanding their rights. (R2)

Usually in meetings [...]. (R8)

Agreements with the person in charge of the team and decisions taken with the consent of everybody. (R16)

We reach a common ground, usually in meetings and debates. (R29)

In meetings with the coordination or with competent sectors. (R34)

On the other hand, some participants were apathetic or unmotivated regarding the resolution of ethical issues and related the conflicts to the management, the local team and the lack of supervision:

Many Nursing professionals [...] even though they have knowledge on the Code of Ethics, often can't solve the issues that arise in some situations. (R3)

The Code of Ethics is not often debated. (R6)

[...] some colleagues like to create controversy and to crosstalk, generating a hostile work environment. (R14)

[...] do not seek legal channels and usually magnify the fact by committing other ethical infractions. (R18)

In certain places and sectors the Code is not used among professionals. (R21)
[...] I notice omission on the subject; professionals generally do not believe in COREN's decisiveness through the Code of Ethics. (R25)

Many times, even if you want to be ethical in certain situations, you have to keep quiet. (R26)

Registering in occurrence books and taking the information to nursing chiefs, often in the wrong way [...]. (R27)

The presence of a Nursing Ethics Board in the institution was highlighted by some participants, as well as the possibility to make direct complaints to the body responsible for supervising the professionals in the region:

[...] usually are solved when these conflicts intensify, thus leading them to seek the institution's responsible committee. (R3)

We have an ethics committee at our place of work. (R5)

Consulting the COREN. (R11)

[...] rarely use formal complaints and the ethics committee. (R13)

First going to the ethics committee [...] and/or referring to the superior institutions, the COREN/COFEN system. (R22)

[...] directing their doubts to the Regional Nursing Council, sending letters or addressing the institution personally. (R30)

\section{DISCUSSION}

Regarding the characterization of the participants, data from the nursing profile carried out by Fiocruz, under the responsibility of the Nucleus of Studies and Research in Human Resources in Health, of the National School of Public Health Sérgio Arouca (Nerhus/ENSP/Fiocruz), in partnership with the Federal Nursing Council (Cofen), showed that, currently, in the country, the professionals are $80 \%$ (eighty percent) technicians and nursing assistants and $20 \%$ (twenty percent) nurses; the data also shows that the nursing team is predominantly female, with $84.6 \%$ (eighty-four and six tenths percent) women ${ }^{(9)}$. However, over the last few decades, the presence of men in this area has been growing: in the early 1990s it reached $2 \%$ (two percent) or $3 \%$ (three percent), and nowadays it already reaches 15\% (fifteen percent), working in the three categories ${ }^{(10)}$.

Regarding the deontological ethics within the profession, the limited knowledge of nursing workers regarding their Code of Ethics may create a significant distance between the work actually performed and the legal and ethical aspects. For this reason, it is necessary to expand the debates on the Nursing Code of Ethics, approved by Resolution no. 311/2007 of the Federal Nursing Council ${ }^{(11)}$.

It is the right of the nursing professional to expand and consolidate their technical, scientific and cultural knowledge in order to guide their professional practice and support the defense of the rights and interests of the profession and of society, backed by the Code of Ethics. It is the professional's duty to exercise the profession with 
[...] justice, commitment, equity, decisiveness, dignity, competence, responsibility, honesty and loyalty and, through their knowledge, base their relations on law, prudence, respect, solidarity and on the diversity of opinions and ideological positions ${ }^{(1)}$.

It is important to promote a culture of ethics in the daily professional practice, considering the codes as a compilation of laws or regulations that govern human relationships, assuring people their rights, but also listing their duties. However, scientific and technological developments must be taken into account, since these advancements will certainly require adaptation of the practice and, perhaps, redistribution of functions in the multi-professional team and alterations in the current legislation ${ }^{(12)}$.

On the first category, "Conception of professional ethics in nursing practice", the understanding of the professionals on the Code of Ethics contributes to responsible actions and to their autonomy as professionals in the healthcare team. However, some limitations in their comprehensions were found in this study. The lack of understanding or insufficient knowledge regarding the Code of Ethics may make the nursing professional undervalued among other health professionals in the job market.

Law no. 7.498/86 regulates the practice of the nursing profession in Brazil, dividing it into the categories of nurse, technician and nursing assistant, with different competences and activities ${ }^{(13)}$. However, all categories are subordinate to the values and regulations of the profession, which are the basis for the ethical decisions taken in accordance with the Code of Ethics of Nursing Professionals, approved by Resolution No. 311/2007 of the Federal Nursing Council(14). The code determines, for example, that nursing technicians and assistants who receive specific training can have prerogatives other than those contained in their professional regulations ${ }^{(15)}$.

To deal with the incipient understanding of the Code of Ethics, some councils opted for a campaign to raise awareness among professionals and to disseminate this document, as part of Cofen's plan to empower and value the category, with the purpose of promoting reflections among the nursing professionals about their rights and duties. There is a legislation to guide and protect the professionals, but it is often neglected because the own professional does not know it and, by ignorance or inducement, can infringe $\mathrm{it}^{(16)}$. This initiative should be followed by other Regional Councils, along with the participation of institutional Nursing Ethics Boards.

On the second category, "Interpretations of ethics in the practice of care", the answers demonstrate that the participants consider the policies in the Code of Ethics as essential to guarantee an assistance that is safe and has legal support. For that, it is necessary to know, understand and apply the Code of Ethics in the professional practice.

It should be noted that the acquisition and consolidation of competences are processes initially associated with academic training and developed under the influence of various personal and professional factors ${ }^{(17)}$. The improvement of the professional's ethical behavior includes the process of building an individual and collective conscience, related to the social and professional commitment with the responsibility in the work relations, which has reflections in the scientific and political fields. And, as members of the health team, nursing professionals must meet the health needs of the population ${ }^{(1)}$.

Therefore, Cofen regulated the creation of Nursing Ethics Board (CEEn) in health institutions through the Resolution $172 / 94$. These boards are educational, consultative and monitor institutions with the purpose of dealing with the professional and ethical aspects of nursing practice. They are perceived as precursors of major changes and improvements in the institutional context and in the nursing professional scenario. Nursing boards and institutions are important because they contribute decisively in the battles of the professionals, claiming for improvements through the defense of decent working conditions, the dissemination of research that promotes positive changes and the consolidation of health systems based on the principles of equality, comprehensiveness and decisiveness, aiming to fight social inequalities ${ }^{(18-19)}$.

In the third category, "Use of the Code of Ethics in the professional practice", the answers revealed that some professionals use the code of ethics motivated by fear, punishments, liability and demands, while other do not use it due to the presence of other professionals or laymen in the work environment.

Therefore, educational actions addressing deontological aspects in the professional practice can prevent occurrences of unethical events and avoid damages to the patients, to the nursing field and to the institution. Due to the fact they are subjected to ethical infractions or issues on an everyday basis, nursing professionals need to prepare themselves with the bioethical, ethical and legal knowledge available in the legislation and in the Nursing Code of Ethics, which guide the practice of care ${ }^{(20)}$.

The expansion of the role and responsibility of the nurse in the work process is related with other issues involving public health policies and limits of action and autonomy among several professional categories. This is raising discussions about the professional acts considered private or shared, within the concepts of integrality and multidisciplinarity of actions proposed by the Unified Health System ${ }^{(12)}$.

It is clear that the ethical issues present in the personal experiences and in the teaching and work scenario deserve to be highlighted and must be contemplated through the doubts and conflicts that arise in the training process, so that the professionals can be trained to be conscious and responsible for their professional action. This should lead to the understanding that the nursing professional can be held accountable for his actions, with legal repercussions in the area of civil liability ${ }^{(21)}$.

It is worth noting that many nursing professionals are still not aware of their rights and duties and the patients'. Therefore, a wider dissemination of the Code of Ethics among these professionals is necessary in order to enable nursing professionals to stand out in the practice in the hospital environment by acting in an ethical, respectful and legal way ${ }^{(22)}$.

Therefore, it is essential that training institutions invest in modifying the curricular components of undergraduate nursing courses and in professional associations, health institutions and in the nursing professional, who should seek professional training and constant updates, in order to ensure a safe and risk-free assistance to the clients ${ }^{(12)}$. 
In the fourth category, "Strategies for solving ethical issues in the professional practice", it is possible to perceive the importance of local and federal boards, which act in favor of the nursing professional regarding ethical demands. It is also possible to identify the presence of a management that is accessible and committed with the well-being of the team.

The statements revealed defensive attitudes, with the intention of supporting professional conduct, expressing indifference with the work environment and hostility with the possibility of ethical conflicts in the workplace. It is worth mentioning the increasing number of complaints against professionals (technicians, assistants and nurses) involving wrongful conduct or inadequate procedures in health care services, many of which with national repercussion ${ }^{(23)}$.

Despite the ethical issues and conflicts of values, it is important that the rights of the patient and the duties of the professional are respected. The professionals must remain up to date on the deontological aspects that must guide their behavior, positioning themselves in a critical and reflexive manner when facing moral dilemmas that are present in the daily practice of the profession. Reflection about responsibility and competence is a guiding tool for decision-making based on legal and ethical principles ${ }^{(24)}$.

For the resolution of ethical dilemmas in the professional practice, the study participants pointed out individual attitudes involving discussions with nursing managers and reports to the Nursing Ethics Board. For some participants, the group council has no credibility. Thus, work conflicts can be understood as an effort emerged from demands above what can be produced regarding conscience and interests. Regarding conscience, these demands begin when one imposes a personal belief on others. And regarding interests, it starts when an individual explores his position for personal gain or for the benefit of a family member(25-26).

It is worth noting that in order to strengthen the ethical principles in nursing, the Nursing Ethics Board assumes, through the delegation of the Regional Nursing Boards, the role of properly providing nursing services in health institutions, thus assuming educational, consultation and monitoring functions regarding the professional and ethical practice of nursing professionals. These institutions must act in a preventive manner, raising awareness and educating the professional in the exercise of their legal duties and in the need to guarantee the patient's safety ${ }^{(13)}$.

\section{Study limitations}

The extraction of the data collected in this study was difficult, considering the limitations and the incoherence of some statements for the questions asked, which can be pointed out as limitations of the study. However, it was possible to identify thematic categories that revealed the essence of the answers and allowed the accomplishment of the objectives of the study.

\section{Contributions to the nursing area}

Therefore, promoting discussions about the Professional Code of Ethics is of great importance, since this study demonstrated that it represents an instrument to guide the professional practice, achieve a better quality of care and produce less conflictive personal relationships. To that end, it is imperative that professionals are able to read between the lines of this regulation and to apply it in their daily practices.

\section{FINAL CONSIDERATIONS}

The Code of Ethics of Nursing Professionals is a normative instrument that directs the practice in the different fields, whether in care, teaching or research, so that the professional can carry out a healthy work activity and find in between lines guidance for taking ethical actions, free of malpractice, recklessness and negligence. To that end, it is necessary that all professionals in this area know, understand and comply with the basis and principles that guide an ethical and safe professional practice, in order to ensure quality assistance and respect for human dignity.

Regarding the understanding of the Professional Code of Ethics, the results revealed that some nursing professionals correctly grasp its meaning, while others showed a limited understanding based on jargon. This may be a concern for nursing management and for the members of the institution's Nursing Ethics Board, suggesting a need for more frequent discussions on ethical dilemmas in the decision-making process.

This study is expected to collaborate as an incentive tool in the search for knowledge leading to good ethical conduct in the actions taken by the nursing professionals, enabling their empowerment based on critical analysis of the reality from the point of view of the Code of Ethics of their profession.

In this context, some attitudes can be understood as essential to practice nursing with ethics, such as: discussions between team members and management, in order to identify problematic circumstances and solutions; inclusion of these professionals in organizational policies that value the human and social dimension; incentives to participate in nursing ethics boards in the institutions; participation in the process of permanent education, addressing ethical actions and having the Nursing Code of Ethics as parameter.

\section{REFERENCES}

1. Conselho Regional de Enfermagem da Paraíba. Legislação básica para o exercício da profissão. 3.ed. COREN-PB, João Pessoa: COREN-PB; 2012.

2. Leal DF, Rauber JJ. A concepção de ética dos profissionais da enfermagem. Rev Min Enferm[Internet]. 2012 [cited 2015 Jul 20];16(4):554-63. Available from: http://www.reme.org.br/artigo/detalhes/561

3. Schneider DG, Ramos FRS. Processos éticos de enfermagem no Estado de Santa Catarina: caracterização de elementos fáticos. 
Rev Latino-Am Enfermagem [Internet]. 2012[cited 2015 Jun 20];20(4):(09 telas). Available from: http://www.scielo.br/pdf/rlae/ v20n4/pt_15.pdf

4. Brasil. Ministério da Saúde. Conselho Nacional de Saúde. Resolução no 466 de 12 de dezembro de 2012: normas para pesquisa em seres humanos [Internet]. 2012 [cited 2016 Oct 15]. Brasília (DF). Available from: http://conselho.saude.gov.br/resolucoes/2012/ Reso466.pdf

5. Gil AC. Como elaborar projeto de pesquisa. 4. ed. São Paulo: Atlas, 2008.

6. Minayo MCS. O desafio do conhecimento: pesquisa qualitativa em saúde. 12.ed. Rio Janeiro: Hucitec/Abrasco, 2010.

7. Richardson RJ. Pesquisa Social: métodos e técnicas. 3.ed. São Paulo: Atlas, 2009.

8. Bardin L. Análise de conteúdo. 70ª Ed. Lisboa: Edições, 2011.

9. Escola Nacional de Saúde Pública. Perfil da enfermagem: jornais enfocam insegurança no trabalho [Internet]. 2015 [cited 2015 Jul 08]. Available from: http://www.ensp.fiocruz.br/portal-ensp/informe/site/materia/detalhe/37880

10. Conselho Federal de Enfermagem. A enfermagem como ela é[Internet]. 2015[cited 2015 Jul 20]. Available from: http://www. cofen.gov.br/pesquisa-inedita-traca-perfil-da enfermagem_31258.html

11. Pereira MS. Lei do exercício profissional de enfermagem e a autonomia profissional do enfermeiro. Enferm Foco[Internet]. 2013[cited 2015 Jul 08];4(3,4):171-4. Available from: http://revista.portalcofen.gov.br/index.php/enfermagem/article/view/543/226

12. Fakih FT, Freitas GF, Secoli SR. Medicação: aspectos ético-legais no âmbito da enfermagem. Rev Bras Enferm[Internet]. 2009 [cited 2015 Jul 08];62(1):132-5. Available from: http://www.scielo.br/pdf/reben/v62n1/20.pdf

13. Conselho Regional de Enfermagem. Corem-SP. Comissão de Ética de Enfermagem [Internet]. 2011[cited 2015 Jul 08]. Available from: http://www.coren-sp.gov.br/node/3536

14. Conselho Federal de Enfermagem. Código de Ética dos Profissionais de Enfermagem [Internet]. 2012 [cited 2015 Jul 20]. Available from: http://www.cofen.gov.br/wpcontent/uploads/2012/03/resolucao_311_anexo.pdf

15. Ribeiro AC, Silva YB. Enfermagem pré-hospitalar no suporte básico de vida: postulados ético-legais da profissão. Cogitare Enferm[Internet]. 2016[cited 2015 Jul 20];21(1):01-8. Available from: revistas.ufpr.br/cogitare/article/download/42118/27507

16. Conselho Regional de Enfermagem. COREN-RS inicia grande campanha de divulgação do Código de Ética [Internet]. 2012 [cited 2014 Feb 21]. Available from: http://www.cofen.gov.br/coren-rs-inicia-grande-campanha-de-divulgacao-do-codigo-deetica_17544.html

17. Zangão MO, Mendes FRP. Competências relacionais e preservação da intimidade no processo de cuidar. Rev Bras Enferm[Internet]. 2015[cited 2015 Jul 20];68(2):191-7. Available from: http://www.scielo.br/pdf/reben/v68n2/0034-7167-reben-68-02-0191.pdf

18. Conselho Regional de Enfermagem. COREN-RJ. Código de ética de enfermagem [Internet]. 2013[cited 2015 Jul 08]. Available from: http://www.corenrj.org.br/pdfs/CodigoDeEticaAbril2013.pdf

19. Santos JFE, Santos RM, Costa LMC, Almeida LMWS, Macêdo AC, Santos TCF. Importância das organizações civis de enfermagem: revisão integrativa da literatura. Rev Bras Enferm[Internet]. 2016 [cited 2016 Oct 15];69(3):610-8. Available from: http://www. scielo.br/pdf/reben/v69n3/0034-7167-reben-69-03-0610.pdf

20. Silva ALNV, Candido MCFS, Duarte SJH, Santos RM. Infrações e ocorrências éticas cometidas pelos profissionais de enfermagem: revisão integrativa. Rev Enferm UFPE[Internet]. 2015[cited 2015 Jul 20];9(1):201-11. Available from: www.revista.ufpe.br/ revistaenfermagem/index.php/revista/.../11227

21. Ramos FRS, Brehmer LCF, Vargas MAO, Schneider DG, Drago LC. Ethics constructed through the process of nurse training: conceptions, spaces and strategies. Rev Latino-Am Enfermagem [Internet]. 2013[cited 2015 Jul 20];21(Spec):[09 telas]. Available from: http://www.scielo.br/pdf/rlae/v21nspe/pt_15.pdf

22. Almeida ABA, Aguiar MGG. A dimensão ética do cuidado de enfermagem ao idoso hospitalizado na perspectiva de enfermeiros. Rev Elet Enf[Internet]. 2011[cited 2015 Jul 08];13(1):42-9. Available from: https://www.revistas.ufg.br/fen/article/view/9462/9159

23. Lenharo M. Denúncias contra profissionais de enfermagem crescem 220\% em 2 anos. Estadão [Internet]. 2013 [cited 2015 Jul 08]. Available from: http://laerciojsilva.blogspot.com.br/2013/02/crescem-as-denuncias-contra.html

24. Fontoura AG, Torre MPS, Rosa DOS, Vieira TT. Processo de formação da enfermeira para um agir ético. Rev Baiana de Enferm [Internet]. 2011 [cited 2015 Jul 20];25(1):59-68. Available from: http://portalseer.ufba.br/index.php/enfermagem/article/view/4936

25. Oliveira MAN, Rosa DOS. Conflitos e dilemas éticos vivenciados pelo enfermeiro no cuidado perioperatório. Cienc Cuid Saude [Internet]. 2015[cited 2016 Oct 15];14(2):1149-56. Available from: http://periodicos.uem.br/ojs/index.php/CiencCuidSaude/ article/view/19423

26. Abreu DPG, Santos SSCS, Silva BTS, et al. Responsabilidades éticas e legais do enfermeiro em relação à administração de medicamentos para pessoas idosas. Rev Enferm Cent O Min [Internet]. 2015[cited 2015 Jul 20];5(3):1905-14. Available from: http://www.seer.ufsj.edu.br/index.php/recom/article/view/750 